\title{
EFEKTIVITAS PENDAMPINGAN PETANI DALAM MENINGKATKAN KESELAMATAN DAN KESEHATAN KERJA DI DESA SUKAINDAH KECAMATAN SUKAKARYA
}

\author{
Edwina Rudyarti1), Mochammad Farhan Dio Santosa'), Dines Jihar Octavia1), Yasir Amri1) \\ 1)Program Studi Keselamatan dan Kesehatan Kerja, Fakultas IImu Vokasi, Universitas Medika Suherman, Cikarang, \\ Jawa Barat, Indonesia \\ Corresponding author : Edwina Rudyarti \\ E-mail : edwina@medikasuherman.ac.id
}

Diterima 25 November 2021, Direvisi 04 Desember 2021, Disetujui 04 Desember 2021

\begin{abstract}
ABSTRAK
Desa Sukaindah merupakan salah satu desa yang berada di Kecamatan Sukakarya, Kabupaten Bekasi. Mayoritas pekerja di desa tersebut adalah petani dengan sistem bekerjanya adalah buruh panggilan dengan menggarap sawah orang lain, permasalahan yang perlu mendapat perhatian terkait keselamatan dan kesehatan kerja dalam penggunaan pestisida bagi petani yaitu pengetahuan dan pemahaman mengenai potensi bahaya risiko penggunaan pestisida dan kesadaran tentang pentingnya pemakaian Alat Pelindung Diri (APD) saat bekerja masih rendah. Program pendampingan masyarakat petani bertujuan untuk meningkatkan keselamatan dan kesehatan kerja melalui 3 tahapan program yaitu: 1. Sosialisasi dan edukasi melalui buku saku yang diberikan kepada para pekerja mengenai dampak risiko bahaya penggunaan pestisida, 2. Pelatihan dan pendampingan pentingnya dalam penggunaan APD, dan 3. Focus Group Discussion mengenai efektivitas pendampingan petani dalam meningkatkan keselamatan dan kesehatan kerja. Sasaran dalam program pendampingan ini adalah masyarakat petani di Desa Sukaindah. Hasil dengan dilaksanakannya kegiatan pengabdian masyarakat ini adalah adanya peningkatan pemahaman dan pengetahuan petani terhadap bahaya risiko penggunaan pestisida dan juga peningkatan petani dalam penggunaan alat pelindung diri (APD) yang baik dan benar. Kesimpulan dari kegiatan ini adalah program pendampingan dalam meningkatkan keselamatan dan kesehatan kerja merupakan metode yang efektif untuk meningkatkan kesadaran mengenai bahaya penggunaan pestisida dan penggunaan alat pelindung diri bagi para petani.
\end{abstract}

Kata kunci: potensi bahaya pestisida; alat pelindung diri (APD); keselamatan dan kesehatan kerja (K3); petani

\begin{abstract}
Sukaindah village is one of the villages are located in kecamatan sukakarya, bekasi district. The majority of workers in the village are farmers with a system of an undeveloped are just labor call by working on other other people rice fields, attention must be given to problems related to the occupational health and safety in the use of pesticides for farmers namely knowledge and understanding of the potential danger risk the use of pesticides and recognition of the importance of the use of the equipment himself apd ) while working is still low. The farmers assistance programs aims to improve work safety and health through the 3 the program which are: 1 .Socialization and education through a book pocket given to workers on the impact of the use of pesticides, risk hazard 2. Training and assistance important in the use of apd, and 3.Focus group discussion regarding concerning assistance increase effectiveness farmers through work safety and health.Goals in this flanking program is the farmers in the village sukaindah.The results by when the public was activities devotion is an increase in the understanding and knowledge of farmers to danger risk the use of pesticides and also elevations farmers through the use of a protective apd ) to ( that is good and right.Conclusion of this activity is to improve assistance programs work safety and health is effective methods to raise awareness of danger the use of a party.
\end{abstract}

Keywords: the potential danger pesticide; self protection instrument ( APD ); work safety and health ( K3 ); farmers 


\section{PENDAHULUAN}

Masyarakat petani merupakah salah satu mata pencaharian yang diunggulkan karena penduduk di Indonesia sebagian besar adalah petani. Sektor pertanian merupakan sektor utama yang dapat memenuhi kebutuhan dari segi pangan. Desa Sukaindah yang terletak di Kecamatan Sukakarya Kabupaten Bekasi memiliki jumlah penduduk sekitar \pm 5000 jiwa merupakan salah satu desa yang berpotensi dalam sektor pertanian dan Sebagian besar masyarakat desa merupakan seorang petani dengan sistem bekerjanya adalah buruh panggilan dengan menggarap sawah orang lain yang bukan kepemilikannya. Dalam proses Bertani dari mulai pembibitan padi sampai persemian mereka masih bersifat tradisional dikerjakan dengan tangan mereka sendiri, seperti proses dalam pembasmian hama padi dengan menggunakan pestisida. Masyarakat masih kurang pemahaman mengenai bahaya yang ditimbulkan akibat penggunakan pestisida bagi petani maupun bagi lingkungan sekitar. Dalam hal ini keselamatan dan Kesehatan kerja merupakan sistem yang didalamnya memiliki aspek perlindungan terhadap pekerja dari potensi penyakit akibat kerja, untuk itu para petani berhak memperoleh pembinaan dan edukasi mengenai potensi bahaya dan risiko yang diakibatkan oleh penggunaan bahan berbahaya dan beracun untuk dapat menunjang produktivitas dari para petani. Kelompok pekerja sektor informal seperti petani masih kurangnya perhatian dari pemerintah (Peraturan Menteri Tenaga Kerja dan Transmigrasi RI No.8, 2010), khususnya bidang keselamatan dan kesehatan kerja karena itu merupakan mata pencaharian masyarakat desa suka indah sehingga seringnya masyarakat mengabaikan risiko bahaya yang ditimbulkan. Permasalahan yang dihadapi petani dalam proses kegiatan bertani menjadi salah satu perhatian khusus dalam kegiatan pengabdian masyarakat seperti kurangnya pengetahuan para pekerja mengenai potensi bahaya dan risiko penggunaan pestisida bagi kesehatan pekerja, bagi lingkungan dan bagi yang mengkonsumsi hasil lahan, serta masih kurangnya pengetahuan, sikap dan perilaku para pekerja dalam pentingnya penggunaan alat pelindung diri ketika bekerja.

Berdasarkan hasil observasi dan wawancara para petani di Desa Sukaindah mengeluhkan banyak memiliki berbagai macam jenis penyakit yang banyak tidak mereka sadari merupakan salah satu akibat dari terpaparnya zat racun yang ditimbulkan dari pestisida secara terus menerus, dan juga terdapatnya kondisi kulit yang kering, pecah-pecah dan mengelupas akibat penggunaan pestisida yang tidak memperhatikan segi-segi keselamatan dan Kesehatan kerja (Mahyuni, 2015). Pestisida sering ditempatkan sembarangan, dan saat menyemprot sering tidak menggunakan pelindung, misalnya tanpa kaos tangan dari plastik, tanpa baju lengan panjang, dan tidak mengenakan masker penutup mulut dan hidung. Juga cara penyemprotannya sering tidak memperhatikan arah angin, sehingga cairan semprot mengenai tubuhnya. Bahkan kadangkadang wadah tempat pestisida digunakan sebagai tempat minum, atau dibuang di sembarang tempat. Kecerobohan yang lain, penggunaan dosis aplikasi sering tidak sesuai anjuran. Dosis dan konsentrasi yang dipakai kadang-kadang ditingkatkan hingga melampaui batas yang disarankan, dengan alasan dosis yang rendah tidak mampu lagi mengendalikan hama dan penyakit tanaman. Tanpa disadari pestisida dapat meracuni masyarakat, hewan, tumbuhan dan lingkungan sekitar melalui oral, dermal dan juga bisa melalui inhalasi atau pernafasan (Andesgur, 2019).

Tujuan dari pengabdian masyarakat ini untuk melakukan upaya meminimalisir terjadinya penyakit akibat kerja bagi petani di Desa Sukaindah yaitu melalui pendampingan peningkatan keselamatan dan Kesehatan keraja dengan sosialisasi dan edukasi mengenai risiko bahaya pestisida bagi masyarakat dan lingkungan yang di dukung dalam pembuatan buku saku (Sulistiyawati, 2011).

\section{METODE}

Metode yang digunakan dalam program pedampingan ini adalah metode Partisipatory Learn-ing and Action (PLA) yaitu metode dalam pemberdayaan masyarakat yang dikenal juga sebagai learning by doing atau belajar sambil bekerja (Rahma \& Rudyarti, 2018). PLA terdiri dari proses belajar melalui ceramah, forum group discussion, curah pendapat, dan lain-lain. Tahapan program pendampingan ini yaitu sebagai berikut:

1. Sosialisasi dan edukasi kepada masyarakat petani mengenai bahaya racun yang diakibatkan penggunaan pestisida, kegiatan ini bertujuan untuk meningkatkan pengetahuan dan pemahaman pekerja terhadap potensi bahaya risiko yang ditimbulkan. Kegiatan ini dilakukan di rumah 
Ketua RW Bapak Muchtar pada tanggal 15 September 2021 yang dihadiri oleh 30 petani terdiri dari 15 laki-laki dan 15 wanita, sedangkan untuk rincian kegiatan tersebut dapat dilihat pada Tabel 1.

Tabel 1. Rincian Kegiatan Sosialisasi

\begin{tabular}{lll}
\hline Hari, tanggal & Jam & Kegiatan \\
\hline $\begin{array}{lll}\text { Rabu, } \\
2021\end{array}$ & September & \\
\cline { 2 - 3 } & $08.30-09.00$ & Registrasi Warga \\
\hline$\underline{09.00-09.30}$ & Pembukaan dan sambutan \\
\hline & $\frac{10.00-10.00}{10.30-11.00}$ & Materi potensi bahaya mengenai pestisida \\
\hline $11.00-11.25$ & Dateri pentingnya APD ketika bekerja \\
\hline $11.25-11.30$ & Saran Penutupan \\
\hline
\end{tabular}

2. Pelatihan dan Pendampingan mengenai alat pelindung diri bagi petani. Kegiatan ini merupakan edukasi dan pendampingan untuk memastikan masyarakat petani dapat mengetahui penggunaan alat pelindung diri yang baik dan benar Ketika bekerja seperti menyemprot pestisida dan kegiatan yang lainnya, dengan rincian kegiatan pendampingan dapat dilihat pada Tabel 2:

Tabel 2. Rincian Kegiatan Pelatihan dan Pendampingan

\begin{tabular}{|c|c|c|}
\hline Hari, tanggal & Tempat & Kegiatan \\
\hline Rabu, 15 September 2021 & Rumah Pak RW & 1. Pelatihan penggunaan APD \\
\hline & & $\begin{array}{l}\text { 2. Review tata cara pemakaian APD di } \\
\text { lapangan }\end{array}$ \\
\hline Kamis, 16 September 2021 & Rumah RW 02 & $\begin{array}{l}\text { Analisis kondisi pekerja dalam penggunaan } \\
\text { 3. APD }\end{array}$ \\
\hline Jumat, 17 September 2021 & Balaidesa & 4. FGD dan Evaluasi \\
\hline
\end{tabular}

\section{Focus Grup Discussion}

Kegiatan ini dilaksanakan bersama dengan orang-orang yang sangat berpengaruh dalam pengambilan kebijakan dan keputusan apabila ada permasalah dalam masyarakat Desa Sukaindah yaitu dengan mengundang Kepala Desa, Sekretaris Desa, Kepala Puskesmas, Sekretaris Puskesmas, perwakilan RW, RT dan gabungan kelompok petani untuk permasalahan fokus grup diskusi adalah mengenai efektivitas pendampingan petani dalam meningkatkan keselamatan dan kesehatan kerja dan didalam FGD ini di pandu menggunakan buku saku mengenai risiko bahaya penggunaan pestisida yang hasilnya akan dilakukan intervensi Bersama dengan pemangku kepentingan untuk dilakukan
Tindakan perbaikan dan juga solusi Bersama untuk mengatasi permasalah para petani dalam penggunaan bahan berbahaya dan beracun bagi tanaman padi yang dikonsumsi sebagai bahan pangan.

\section{HASIL DAN PEMBAHASAN}

Hasil kegiatan yang dilakukan dalam menyelesaikan permasalahan yang terdapat di Desa Sukaindah melalui pendampingan, edukasi dan sosialisasi mengenai bahaya risiko dalam penggunaan pestisida bagi masyarakat petani terutama dalam penggunaan alat pelindung diri dan juga permasalahan keselamatan dan kesehatan kerja yang kerap kali terabaikan oleh pekerja karena banyak masyarakat yang 
mengalami gangguan Kesehatan seperti gangguan pada pernafasan, gangguan pada kulit, dan juga gangguan pada mulut. Secara tidak langsung pestisida dapat meracuni seseorang tanpa menimbulkan rasa sakit yang mendadak dan mengakibatkan keracunan kronik apabila terpapar zat beracun secara terus menerus, sehingga akan menimbulkan penyakit setelah selang waktu yang lama setelah berbulan-bulan atau bertahun. Pestisida yang sering digunakan oleh para petani merupakan berbentuk gas yang paling berbahaya, sedangkan yang berbentuk cair sangat berbahaya bagi kulit karena dapat masuk ke dalam jaringan tubuh melalui pori-pori kulit yang nantinya akan menimbulkan penyakit kanker, cacat tubuh, dan gangguan fungsi organ tubuh lainnya. Selain dapat menimbulkan keracunan langsung dampak negatif dari penggunaan pestisida dapat meracuni orang lain atau masyarakat yang mengkonsumsi bahan pangan yang menngunakan pestisida seperti diakibatkan oleh sisa racun atau residu yang terdapat dalam tanaman ataupun bagian tanaman yang dikonsumsi oleh masyarakat (Abdul Kodir, 2016). Bahan makanan yang dikonsumsi tanpa sadar memiliki kandungan racun pestisida dan dikonsumsi setiap hari dan itu dapat membahayakan masyarakat baik manusia, hewan, maupun lingkungan (Yuantari et al., 2015).

Masyarakat Desa Sukaindah memiliki risiko tinggi terhadap bahaya yang diakibatkan oleh penggunaan pestisida yang tidak terkontrol secara terus menerus, dan banyak masyarakat masih belum paham dampak yang terjadi akibat pestisida, sehingga sebelum adanya pendampingan tim pengabdian masyarakat melakukan pre test pada petani untuk mengetahui pengetahuan awal masyarakat petani terhadap bahaya risiko dari pestisida dan juga tentang pentingnya penggunaan APD (alat pelindung diri). Hasil pre test yang dilakukan oleh tim dapat dilihat pada Gambar 1.

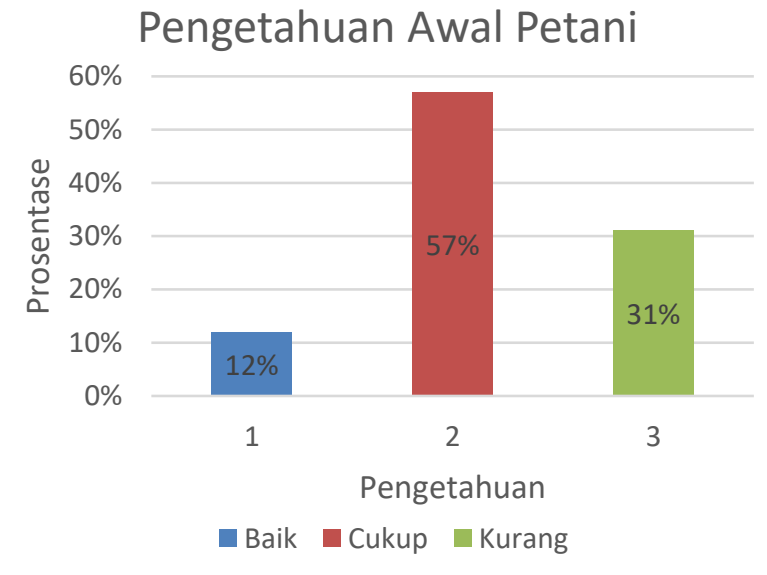

Gambar 1. Pengatahuan Awal Petani di Desa Sukaindah

Hasil pre test dengan beberapa instrument pertanyaan yang diberikan menunjukkan bahwa tingkat pengetahuan awal 30 orang petani dihasilkan prosesntase $12 \%$ memiliki pengetahuan baik, 57\% memiliki pengetahuan cukup dan $31 \%$ memiliki pengetahuan kurang. Dan juga dilakukan wawancara dengan hasil menunjukkan bahwa belum pernah mendapatkan penyuluhan dari Instansi terkait seperti Dinkes dan Disnaker dari segi keselamatan dan kesehatan kerja, maka dari itu tim pengabdian masyarakat melakukan upaya pendampingan untuk dapat memberikan sosialisasi dan edukasi kepada para petani yang berada di Desa Sukaindah, beberapa diantara upaya yang telah dilakukan adalah sebagai berikut:

1. Sosialisasi dan edukasi tentang potensi bahaya risiko penggunaan pestisida bagi petani. Pemahaman potensi bahaya risiko pestisida bertujuan untuk mengenalkan bahaya akibat penggunaan pestisida yang mengandung racun dan dapat menimbulkan penyakit akibat kerja serta memberikan pengaruh yang merugikan bagi Kesehatan atau keselamatan petani, materi yang disampaikan dibuat dalam bentuk buku saku yang disampaikan dalam kegiatan edukasi bersama masyarakat petani dan juga Bersama pemangku kepentingan dari Desa setempat yaitu Kepala Desa, Kepala Puskesmas dan juga RW, dan RT.

a. Observasi ke petani dalam penggunaan pestisida 


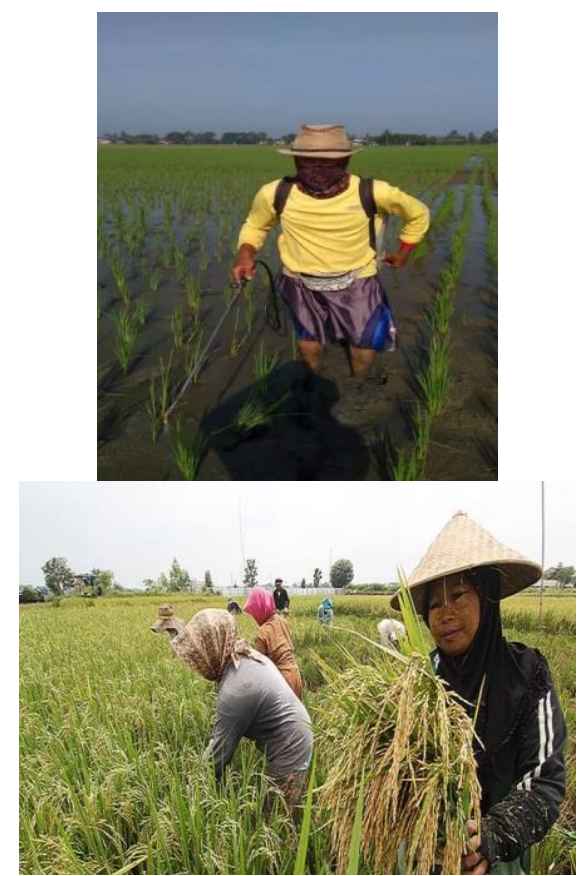

Gambar 2. Petani Desa Sukaindah

b. Kegiatan Sosialisasi kepada masyarakat

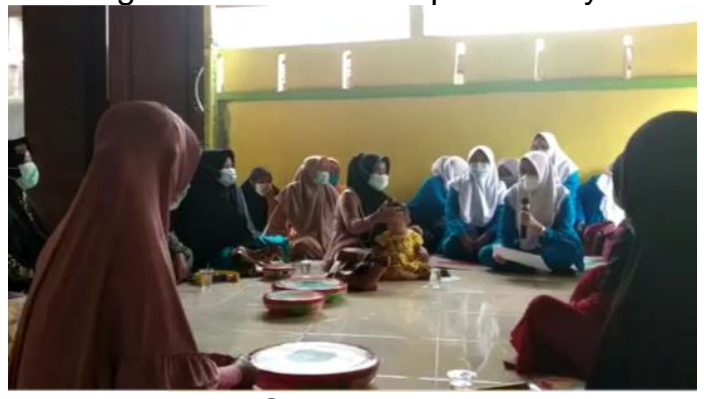

Gambar 3. Sosialisasi dan Edukasi

c. Kegiatan FGD (Focus Group Discussion) mengenai permasalahan yang di hadapi

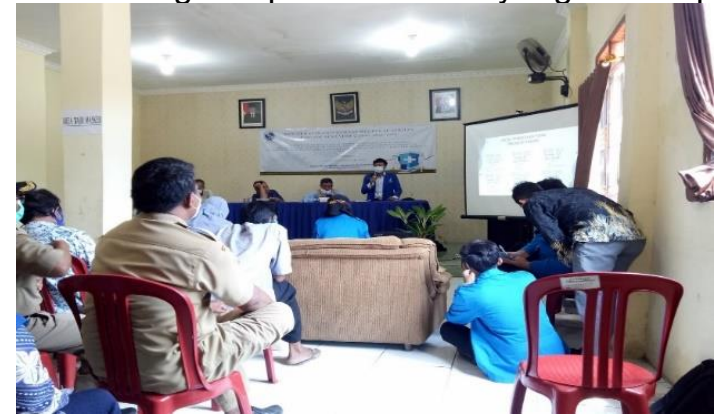

Gambar 4. Focus Group Discussion

2. Edukasi pentingnya penggunaan Alat Pelindung Diri (APD)

Kegiatan ini dilaksanakan melalui door to door dengan tujuan agar pembagian masker dapat terdistribusi dengan baik dan kegiatan edukasi kepada warga juga dapat tersampaikan dengan baik. Dalam edukasi ini tim pengabdian masyarakat menjelaskan alat pelindung diri apa saja yang digunakan sesuai dengan jenis pekerjaan, dampak negatif yang dapat terjadi Ketika tidak menggunakan alat pelindung diri serta menjelaskan mengenai cara meminimalisir risiko bahaya yang dapat ditimbulkan apabila menggunakan alat pelindung diri (Ramadhan, 2017). Tim pengabdian masyarakat juga mebagikan masker kepada masyarakat dengan tujuan selain memberikan pendampingan serta edukasi mengenai alat pelindung diri untuk keselamatan dan kesehatan kerja juga dapat membantu pemerintah dalam mencegar rantai penyebaran virus Covid-19 yang saat ini sedang menjadi pandemic di Indonesia. Edukasi merupakan suatu proses pembelajaran dengan lebih menekankan pada praktik dari pada teori dengan tujuan meningkatkan kemampuan dalam satu atau beberapa jenis keter-ampilan tertentu. Edukasi ini bertujuan untuk memberikan pengetahuan dan keterampilan kepada pekerja agar dapat mengidentifikasi APD apa yang tepat digunakan sesuai pekerjaan mereka. Alat Pelindung Diri selanjutnya disingkat APD adalah suatu alat yang mempunyai ke-mampuan untuk melindungi seorang yang fungsinya mengisolasi sebagian atau seluruh tubuh dari potensi bahaya di tempat kerja (Phuspa \& Rudyarti, 2017). Setelah tim pengabdian memberikan edukasi pekerja diminta untuk menggunakan APD ketika bekerja menyemprot tanaman padi selama 5 hari. APD yang digunakan pekerja yaitu seperti yang ditunjukkan pada Tabel 3 . 
Tabel 3. APD bagi Petani

\begin{tabular}{lll}
\hline No. Pekerjaan & Gestisida \\
\hline 1. $\begin{array}{l}\text { Masker untuk melindungi dari } \\
\text { cipratan dan gas dari pestisida }\end{array}$ & $\begin{array}{l}\text { Sarung tangan untuk melindungi } \\
\text { kulit dari bahan kimia beracun }\end{array}$ \\
\hline
\end{tabular}

Kegiatan wawancara juga dilakukan untuk melihat tata cara para petani memakai alat pelindung diri. Masyarakat banyak mengeluhkan dalam pemakaian alat pelindung diri ketika bekerja beberapa menyatakan pendapat bahwa merasa tidak nyaman ketika pertama kali meamakai alat pelindung diri seperti masker banyak Sebagian petani menyampaikan sulitnya bernafas, panas, dan ketika memakai sarung tangan juga tidak leluasa dan dirasa berat ketika memakai sepatu boot, akan tetapi setelah diberikannya sosialisasi dan edukasi dalam pendampingan treatment dalam pemakaian 5 hari menggunakan alat pelindung diri mereka lamakelamaan mulai terbiasa dan mulai nyaman, dan mulai terlihat bahwa mereka gatal-gatal dan kering di tangan sudah mulai berkurang dan kaki mereka terlihat bersih dan tidak merasakan perih, penggunaan masker pun sekarang rutin untuk dipakai setiap hari tidak hanya ketika bekerja tetapi juga wajib dipakai setiap hari karena memang situasi kondisi sedang adanya wabah pandemic Covid-19 sehingga mereka sudah mulai memahami bahwa pemakaian alat pelindung diri merupakan kebutuhan mendasar yang harus selalu diterapkan demi menjaga 
keselamatan dan Kesehatan kerja. Setelah adanya kegiatan pendampingan dalam pemahaman mengenai bahaya risiko pada penggunaan pestisida melalui sosialisasi dan edukasi pada masyarakat petani serta tata cara dalam pemakaian APD yang baik dan benar maka dilakukan kegiatan post test untuk mengetahui efektivitas kegiatan pendampingan dengan hasil yang diperoleh ditunjukkan pada Gambar 4.

\section{Pengetahuan Akhir Petani}

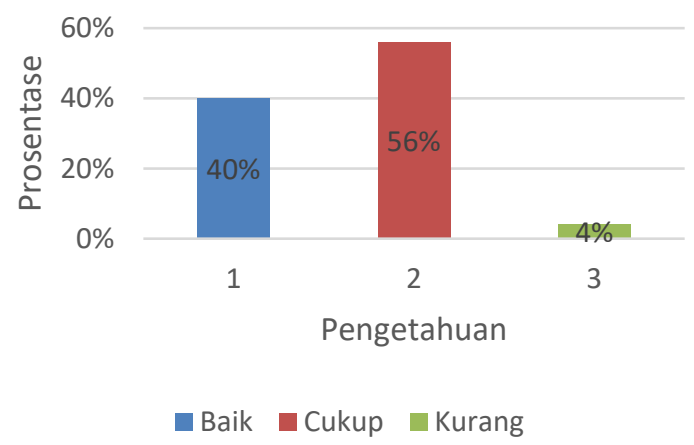

Gambar 4. Persentase Pengetahuan Akhir Warga Petani.

Kegiatan post test yang telah dilakukan menunjukkan bahwa pendampingan sosialisasi dan edukasi mengenai bahaya dan risiko penggunaan pestisida serta dalam penggunaan alat pelindung diri mampu meningkatkan pengetahuan masyarakat petani tentang bahaya risiko pestisida dan pentingnya dalam penggunaan alat pelindung diri dengan perolehan prosentase $40 \%$ baik, $56 \%$ cukup, dalam hal ini berdasarkan dari jurnal penelitian Rudyarti (2017), bahwa pemberian informasi tentang alat pelindung diri dapat meningkatkan perilaku pekerja untuk menggunakan alat pelindung diri agar terhindar dari kecelakaan akibat kerja dan pemberian informasi serta edukasi merupakan hal yang paling benar dilakukan untuk menumbuhkan kesadaran dalam sikap dan berperilaku (Rudyarti, 2017).

\section{SIMPULAN DAN SARAN}

Kesimpulan yang dapat diambil dari kegiatan yang telah dilakukan dalam pemberian sosialisasi dan edukasi mengenai risiko bahaya penggunaan pestisida dan pentingnya penggunaan alat pelindung diri untuk dapat meminimalisir risiko dari dampak yang timbul akibat penggunaan pestisida, yaitu dapat meningkatkan pengetahuan dan pemahaman petani dengan prosentase $40 \%$. Untuk pendampingan dalam penggunaan alat pelindung diri masyarakat juga sudah mulai terbiasa bekerja dengan memakai alat pelindung diri. Sedangkan untuk program kelanjutan adalah mengenai pelatihan cara mengolah bio-pestisida sebagai bahan alternatif pengganti pestisida agar ramah lingkungan

\section{UCAPAN TERIMA KASIH}

Ucapan terima kasih diberikan kepada masyarakat petani, perangkat desa yang telah bersedia membantu dalam pelaksanaan kegiatan pengabdian masyarakat ini, dan untuk Dosen Pembimbing Lapangan yang telah bersedia membimbing, serta segenap teman-teman yang sudah berkontribusi dalam kegiatan Pengabdian Masyarakat di Desa Sukaindah.

\section{DAFTAR RUJUKAN}

Abdul Kodir, K. (2016). PENGARUH PENGGUNAAN PESTISIDA NABATI TERHADAP PERTUMBUHAN DAN HASIL PADI SAWAH INPARI 14.

Andesgur, I. (2019). Analisa Kebijakan Hukum Lingkungan dalam Pengelolaan Pestisida. BESTUUR, 7(2), 93-105.

Mahyuni, E. L. (2015). Faktor risiko dalam penggunaan pestisida pada petani di Berastagi Kabupaten Karo 2014. Kes Mas: Jurnal Fakultas Kesehatan Masyarakat Universitas Ahmad Daulan, 9(1), 25014.

Peraturan Menteri Tenaga Kerja dan Transmigrasi RI No.8. (2010). Peraturan Menteri Tenaga Kerja dan Tramigrasi Republik Indonesia No. PER.08/MEN/2010 Ten-tang Alat Pelindung Diri.

Phuspa, S. M., \& Rudyarti, E. (2017). The Relationship of Belief, Experience, Knowledge, and Attitudes Toward Safety Behavior of Construction Workers at University $X$ Ponorogo. Indonesian Journal for Health Sciences, 1(2), 34-41.

Rahma, R. A. A., \& Rudyarti, E. (2018). Efektivitas Pendampingan Pekerja dalam Meningkatkan Keselamatan dan Kesehatan Kerja di Sentra Industri Gamelan Kabupaten Ponorogo. Khadimul Ummah, 1(2), 93-101.

Ramadhan, F. (2017). Analisis Kesehatan dan Keselamatan Kerja (K3) Menggunakan Hazard Identification Risk Assessment and Risk Control (HIRARC). Prosiding Seminar Nasional Riset Terapan| SENASSET, 164-169. 
Rudyarti, E. (2017). The Relationship Of Safety And Health Knowledge And Attitude Of Use Of Self-Protector Equipment With Work Accident Accident In Batik Knife Crafts In PT. $X$. Journal of Industrial Hygiene and Occupational Health, 2(1), 31-43.

Sulistiyawati, D. (2011). Pengelolaan bahan kimia sebagai upaya pencegahan kecelakaan dan penyakit akibat kerja di PT. Heinz $A B C$ Indonesia Karawang Jawa Barat.

Yuantari, M. G. C., Widianarko, B., \& Sunoko, H. R. (2015). Analisis risiko pajanan pestisida terhadap kesehatan petani. KEMAS: Jurnal Kesehatan Masyarakat, 10(2), 239-245. 